\title{
Modulation impact of Diazinon forms on gene expression profile and DNA damage pathway in male mice
}

\author{
Neama I. Ali ${ }^{1}$, Lamiaa M. Salem¹, Sawsan Y. Elateek ${ }^{2}$, Wagdy K. B. Khali1 ${ }^{1 *}$ \\ ${ }^{1}$ Cell Biology Department, National Research Centre, Dokki, Egypt. \\ ${ }^{2}$ Department of Genetics, Faculty of Agriculture, Ain Shams University, Cairo, Egypt.
}

\section{ARTICLE INFO \\ Received on: $11 / 03 / 2020$ \\ Accepted on: 22/06/2020 \\ Available online: 05/08/2020}

Key words:

Diazinon, apoptosis, ROS

formation, DNA damage,

gene expression.

\begin{abstract}
Diazinon (DZN) is an organophosphate pesticide used widely in agriculture. Unexpectedly, the pure pesticide compounds are less toxic than its commercial formulations. Therefore, the present study aimed to compare between the commercial DZN formulation Basudin $60 \mathrm{EM} \otimes$ and active ingredients forms of DZN to find the nontoxic form. Several groups of male mice were treated with different doses (1/40,1/20, and 1/10 of LD50) of commercial formulation and active ingredients of DZN pesticide for 4 weeks. A quantitative Real-Time PCR (RT-PCR) was conducted to investigate the expression of TNF- $\alpha$, p53, and Caspase- 3 genes. Furthermore, the effect of both forms of DZN on intracellular Reactive Oxygen Species (ROS) generation and DNA damage was studied. The results showed that the TNF- $\alpha, \mathrm{p} 53$, and Caspase- 3 expression levels were increased in commercial formulationtreated mice than those treated with active ingredient form. Moreover, the commercial formulation form was able to increase ROS generation and induce DNA damage much more than the active ingredient-treated mice. The results concluded that not only the organophosphates but also the other byproducts affect the cellular responses to cytokine and apoptotic elements through alteration in the mRNA expression by increasing the levels of free radical generation.
\end{abstract}

\section{INTRODUCTION}

There is a fact that various disorders in animals and humans are observed due to continuous exposure to pesticides. The commonly used pesticides in agriculture are the organophosphates, which are considered as neurotoxic agents and act as acetylcholinesterase inhibitors (Allison et al., 2004). Notably, as compared to organochlorine pesticides, they are less persistent and more toxic to mammals (Casas et al., 2010; Lopez et al., 1986). One of the thionophosphorous organophosphate groups is diazinon (DZN), namely, 0, 0-diethyl-0-(2-isopropyl4-methyl-6-pyrimidinyl phosphorothionate. DZN is the focal point of this study and has been used because of its effects on a variety of insects in farms and households (Cox, 2000). DZN is a colorless fluid and is mainly absorbed through the skin, inhalation,

"Corresponding Author

Wagdy K. B. Khalil, Cell Biology Department, National Research Centre, Dokki,Egypt.E-mail:wkbassaly@gmail.com,wagdykh@yahoo.com and ingestion resulting in chronic symptoms such as excessive salivary secretion, nausea, disorientation, headache, irritability, alertness, and diarrhea (Vettorazzi and Vettorazzi, 1975). DZN is degraded and rapidly excreted in several tissues such as the kidney and liver by hydrolysis and oxidation processes (Cantor et al., 1992). Based on several in vivo and in vitro studies, DZN showed some related toxicity, mortality, genotoxic and cytotoxic effects on animals (Ducolomb et al., 2009; Ogutch et al., 2006) and humans (Altamirano-Lozano et al., 1989; Hatjian et al., 2000; Satar et al., 2009; Sobti et al., 1982). Furthermore, its commercial formulation showed toxicity-induced failure in the fertilization of the ova in vitro and further development of the embryo (Ducolomb et al., 2009). On the other hand, some in vitro studies showed controversial results as it showed no effect on sister chromatid exchange and the low incidence of chromosomal aberrations was observed (Chen et al., 1981; Kuroda et al., 1992; Lopez et al., 1986) or there is no induction or a very weak increase in the number of micronucleated lymphocytes (Bianchi-Santamaria et al., 1997) and inhibition of cell proliferation in human cells 
(Colovic et al., 2010). These contradictory findings stress the need to use different assays along with different test materials to further study the genotoxicity of DZN.

Exposure of DZN to the surrounding environment such as U.V. radiation, elevated heat, moisture, and air results in many degradable product formations such as tetraethyl dithiopyrophosphate (S, S-TEPP, and sulfo-TEPP) and tetraethylmonothiopyrophosphate (O, S-TEPP, and mono-TEPP) (Wang et al., 2019). Furthermore, metal ions from corroded metal containers act as catalytic agents to decompose DZN to these toxic products (Zhang et al., 2019). Hence, water exclusion of DZN source material in the hydrocarbon-based/emulsifiable concentrate formulated products results in DZN stability, and its commercial formulations prevent such a formation of breakdown products.

Therefore, the main objective of this study was to investigate the effect of the commercial formulation form and the active ingredient form of DZN inducing potential toxicity to find a less toxic form of the organophosphate pesticide to be used as a safe form for agricultural and human use.

\section{MATERIALS AND METHODS}

\section{Chemicals}

Commercial DZN formulation Basudin 60EM ${ }^{\circledR}$ was purchased from the private market, Giza, Egypt. Trizol reagent for RNA isolation was purchased from Invitrogen (USA). The kits for reverse transcription (RT) and PCR reaction were purchased from Fermentas (Germany). Moreover, other reagents and chemicals were of high analytical grade and purchased from local commercial suppliers in Egypt.

\section{Animals}

A total of 70 adult Swiss albino male mice (22-26 g in average) were used in this study. The animals were obtained from the National Research Centre (NRC), Giza, Egypt, and received standard laboratory diet as well as water ad libitum. The animals were housed in polycarbonate cages free from any chemical contamination source and allocated in several groups (10 mice each) at controlled temperature and light conditions. According to the guidelines of the Ethical Committee of NRC, all the animals received humane care. These guidelines were performed according to the National Institutes of Health Guide recommendations (Publication No. 85-23, revised 1985). The in vivo experiment of this study has received the Ethical Clearance Approval from the Ethical Committee of AS University (Number of 0147 at $11 / 2019)$.

\section{Experimental setup}

The groups of animals (10 mice each) were designed as follows: Group 1 contained control untreated animals, Groups 2-4: mice were injected by single oral dose per a week with commercial DZN formulation Basudin 60EM $\AA(1 / 40,1 / 20$, and 1/10 of LD50 dose) according to El-Shenawy et al. (2009) and Muranli et al. (2015) for 4 weeks, and Groups 5-7: mice were injected by single oral dose per a week with DZN pesticide as active ingredient pesticide $(1 / 40,1 / 20$, and $1 / 10$ of LD50 dose) for 4 weeks. By cervical dislocation, all mice were sacrificed at treatment termination after 24 hours of the last supplementation.
Liver and kidney tissues were collected from all animals for molecular and biochemical analyses.

\section{Expression of inflammatory and apoptosis genes}

\section{$R N A$ isolation and $R T$ reaction}

TRIzol ${ }^{\circledR}$ extraction chemical (Invitrogen) was utilized to isolate the total genomic RNA of the liver tissues of all treated mice. After completion of the isolation procedures, the RNA pellet was stored in DEPC-treated water. To digest the potential DNA residues, the pellet of isolated RNA was treated with RNAse-free DNAse kit (Invitrogen, Germany). RNA aliquots were stored at $-20^{\circ} \mathrm{C}$ or utilized immediately for RT (Salem et al., 2018).

First Strand cDNA Synthesis Kit (RevertAidTM, MBI Fermentas) was used to synthesize the cDNA copy from liver tissues via RT reaction. An RT reaction program of $25^{\circ} \mathrm{C}$ for 10 minutes, then $42^{\circ} \mathrm{C}$ for 1 hour, and then $95^{\circ} \mathrm{C}$ for 5 minutes was used to obtain the cDNA copy of the liver genome. Finally, the tubes of reaction containing cDNA copy were collected on ice up to use for cDNA amplification (Khalil et al., 2018).

\section{Quantitative real-time PCR}

SYBR $®$ Premix Ex Taq ${ }^{\mathrm{TM}}$ Kit (Takara, Biotech Co., Ltd.) was used to perform the qRT-PCR analyses using the synthesized cDNA copies from liver tissues. For each reaction, a melting curve profile was conducted. The quantitative values of the target genes were normalized on the expression of the housekeeping gene (Table 1). The $2^{-\Delta \Delta C T}$ method was used to determine the quantitative values of the specific genes to the GAPDH gene.

\section{Determination of ROS formation}

Flow cytometer was used to determine the intracellular Reactive Oxygen Species (ROS) generation in kidney mouse tissues with a specific Dichloro-dihydro-fluorescein diacetate (DCFH-DA) fluorescent probe following single-cell suspensions which was completed. The non-fluorescent compound of DCFHDA was freely taken up into assessed cells. During the reaction, the DCFH compound was oxidized to the fluorescent compound, namely, dichlorofluorescein by cellular oxidation action. Using the DCFH-DA solution, the cellular suspension was loaded and incubated at $37^{\circ} \mathrm{C}$ for 30 minutes. After centrifugation of the samples, the fluorescence of the cells was detected by a flow cytometer (with the emission of $525 \mathrm{~nm}$ and excitation of $488 \mathrm{~nm}$ ). Approximately, $1 \times 10^{5}$ cells for each treatment were counted, and the experiment was carried out in triplicate (Khalil and Abdu, 2013).

Table 1. Primer sequences used for qRT-PCR amplification.

\begin{tabular}{lll}
\hline Gene & Primer sequence $\left(\mathbf{5}^{\prime} \mathbf{-} \mathbf{3}^{\prime}\right)$ & References \\
\hline \multirow{2}{*}{ TNF- $\alpha$} & Forward: ACT GAA CTT CGG GGT GAT TG & Khan et al. (2013) \\
& Reverse: GCT TGG TGG TTT GCT ACG AC & \\
P53 & Forward: CGC AAA AGA AGA AGC CAC TA & Rasmy et al. (2011) \\
& Reverse: TCC ACT CTG GGC ATC CTT & \\
Caspase-3 & Forward: TGA GCA TTG ACA CAA TAC AC & Yonguc et al. (2012) \\
& Reverse: AAG CCG AAA CTC TTC ATC & \\
GAPDH & GTA TTG GGC GCC TGG TCA CC & Khan et al. (2013) \\
\hline
\end{tabular}




\section{Comet assay}

The DNA damage in treated mouse samples using comet assay was performed according to Blasiak et al. (2004). The homogenized liver samples of treated groups were mixed with low melting point agarose and loaded in small pieces on slides which precoated with normal melting agarose. The loaded samples were kept on the slides in the horizontal position for $1 / 2$ hour in the dark environment at $4^{\circ} \mathrm{C}$. Low melting point agarose was then pipetting above the slides including samples, and the slides were left for 30 minutes at $4^{\circ} \mathrm{C}$ to harden and put afterward in lysis buffer for 1 hour. Then, a fresh alkaline unwinding buffer was used to submerge the slides in a dark place for 1 hour at $20^{\circ} \mathrm{C}$. Afterward, electrophoresis $(0.8 \mathrm{~V} / \mathrm{cm}, 300 \mathrm{mAmps})$ for the slides was carried out for 30 minutes to assess the DNA damage in the form of tail migration in 100 cells per each animal. Specific software (TriTek Corp., Comet Score, Sumerduck, VA22742) was used to determine the rate of the DNA damage per sample.

\section{Statistical analysis}

Using general linear model technique of the statistical analysis system, the genetic and biochemical data were analyzed followed by Scheffé's test (SAS Performance Tuning Strategies and Techniques Institute, 2003) to determine the significant differences between all the treatments. The values of the data were expressed as mean \pm SEM. All statements of significance were based on the probability of $p<0.05$.

\section{RESULTS AND DISCUSSION}

Impact of DZN pesticide on the expression of apoptotic and inflammatory genes

Expression of Tumor necrosis factor- $\alpha$ (TNF- $\alpha)$ (such as inflammatory-related gene), p53, and caspase-3 genes (such as apoptotic-related genes) was quantified by qRT-PCR and was monitored to assess the effect of the commercial formulation and the active ingredient of DZN pesticide in liver tissues of male mice (Figs. 1-3).

The results revealed a significant elevation in the expression of TNF- $\alpha$ gene in all treated mice groups with the commercial formulation of DZN pesticide (1/40,1/20, and 1/10 LD50), where the expression levels increased by 2.7-, 3.3-, and 4.5-fold, respectively, compared with the control group (Fig. 1). Moreover, the levels of expression of TNF- $\alpha$ gene were increased in the groups of mice treated with the active ingredient of DZN pesticide compared with the control group, where the expression levels increased by 1.9, 2.2-, and 3.5-fold in the groups of mice treated with $1 / 40,1 / 20$, and 1/10 LD50, respectively (Fig. 1). The results revealed that the expression levels of TNF- $\alpha$ were higher in mice groups treated with the commercial formulation of DZN pesticide than those treated with an active ingredient of DZN pesticide.

Besides, the results showed significant increases in the expression of $\mathrm{p} 53$ and caspase- 3 genes in all the groups of mice treated with the commercial formulation of DZN pesticide $(1 / 40,1 / 20$, and

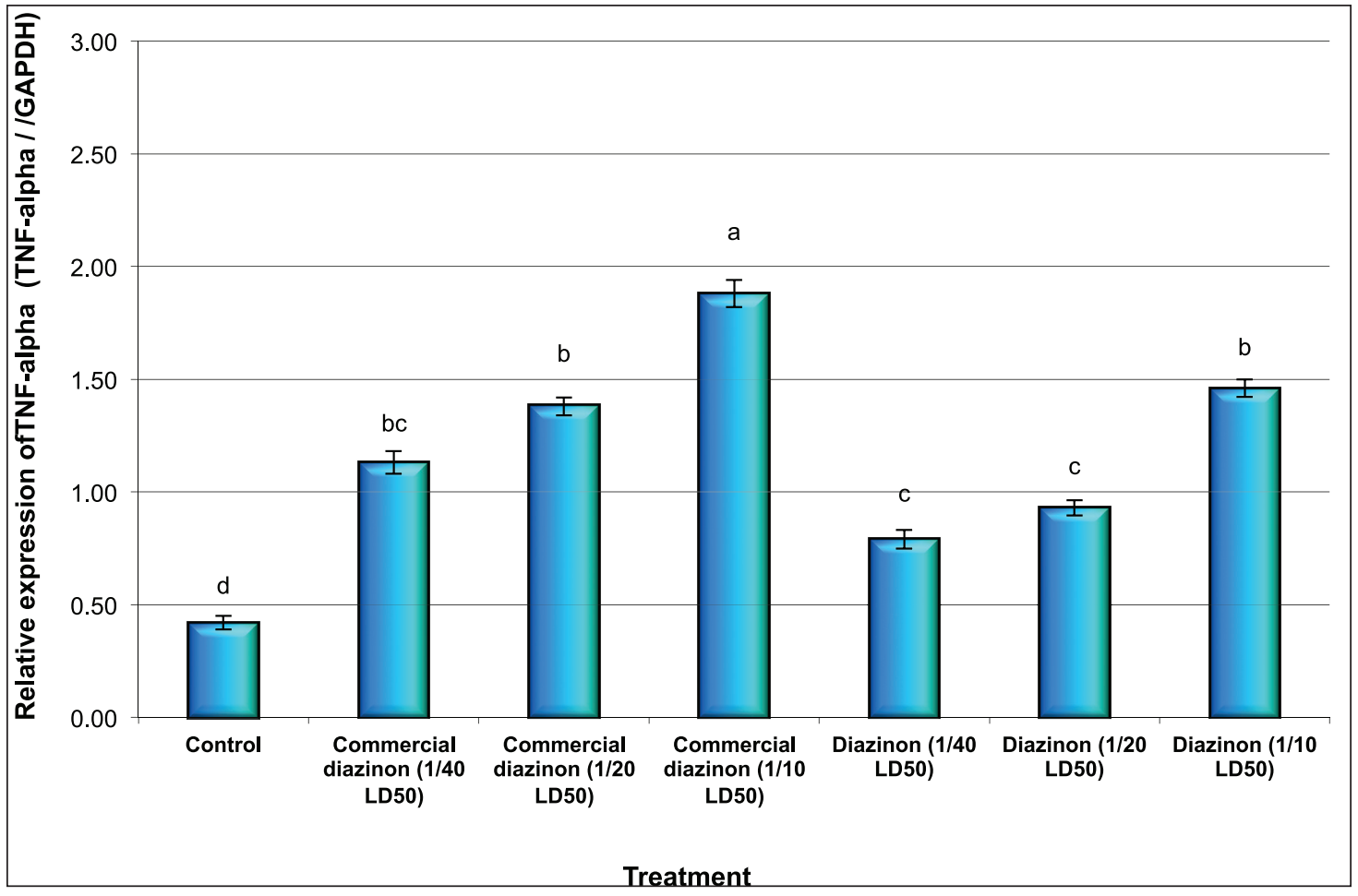

Figure 1. Quantitative RT-PCR confirmation of TNF-alpha gene in liver issues of male mice exposed to different concentration of commercial diazinon formulation Basudin $60 \mathrm{EM}^{\circledR}$ and active ingredient of Diazinon. Data are presented as mean \pm SEM. a,b,c Mean values within tissue with unlike superscript letters were significantly different ( $\mathrm{a}: P<0.01, \mathrm{~b}: P<0.05$ ). 


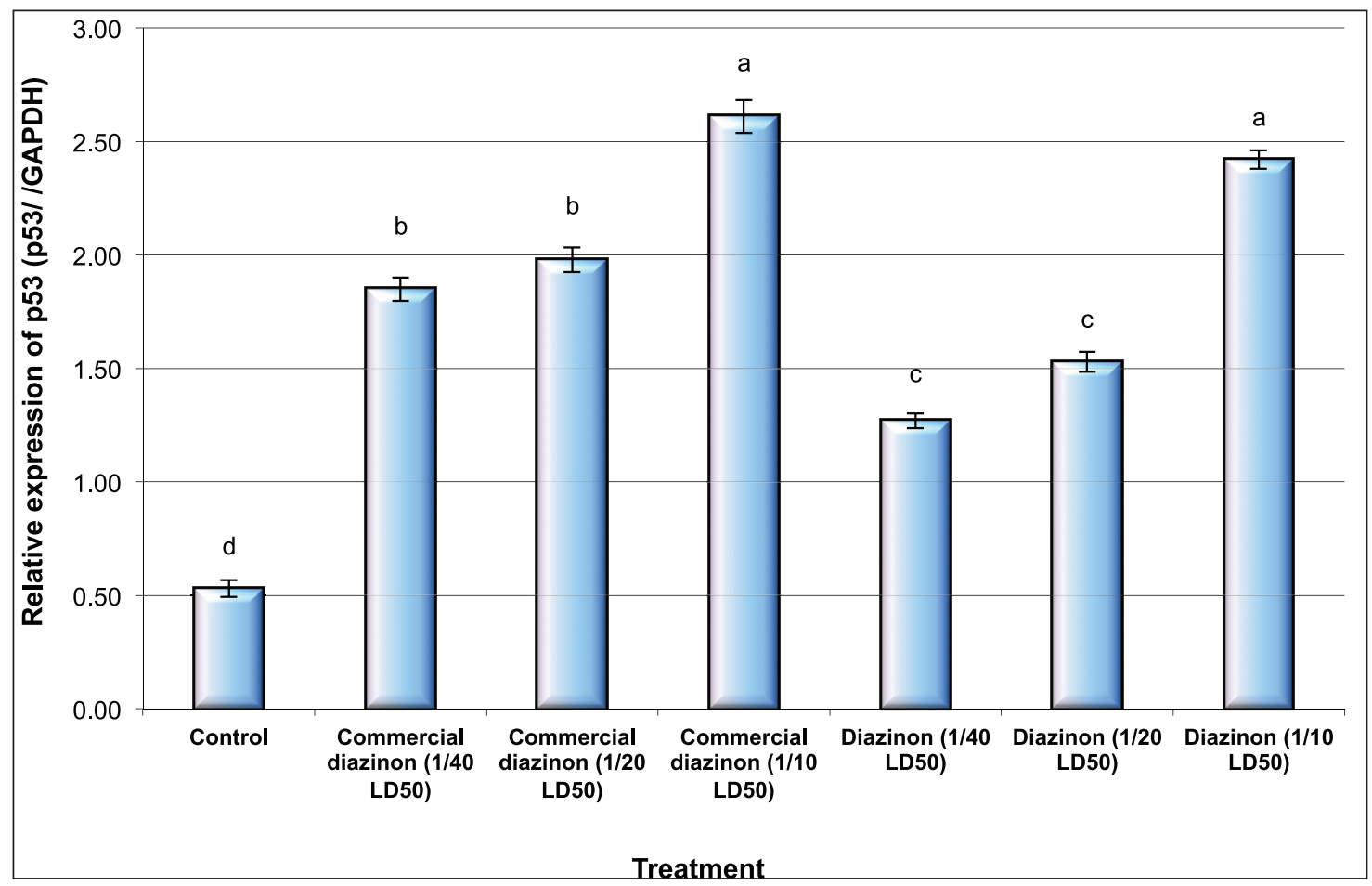

Figure 2. Quantitative RT-PCR confirmation of 553 gene in liver issues of male mice exposed to different concentration of commercial diazinon formulation Basudin $60 \mathrm{EM}^{\circledR}$ and active ingredient of Diazinon. Data are presented as mean \pm SEM. a,b,c Mean values within tissue with unlike superscript letters were significantly different (a: $P<0.01$, b: $P<0.05$ ).

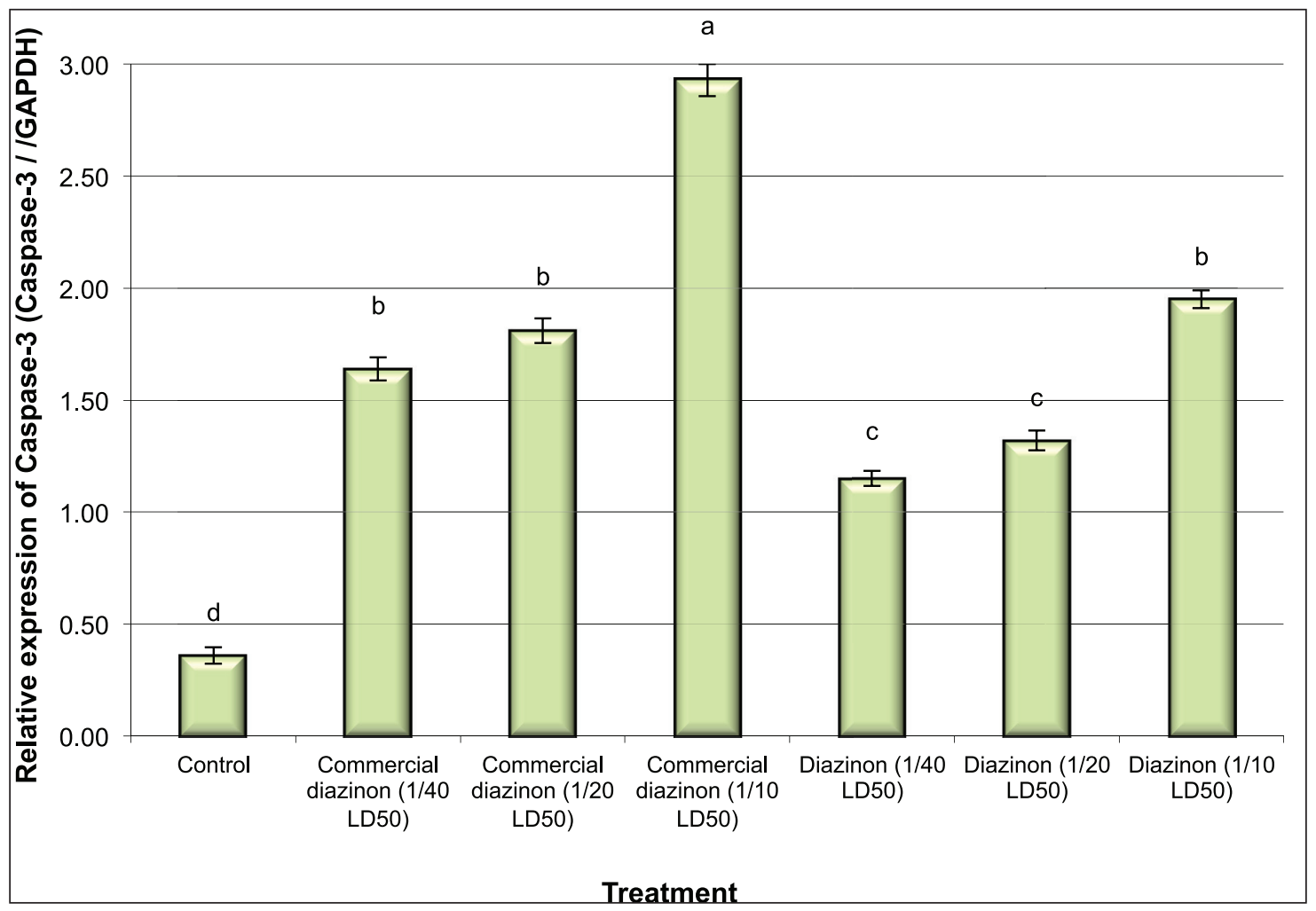

Figure 3. Quantitative RT-PCR confirmation of Caspase-3 gene in liver issues of male mice exposed to different concentration of commercial diazinon formulation Basudin $60 \mathrm{EM}^{\circledR}$ and active ingredient of Diazinon. Data are presented as mean \pm SEM. a,b,c Mean values within tissue with unlike superscript letters were significantly different (a: $P<0.01$, b: $P<0.05$ ). 
1/10 LD50), where the expression levels increased by 3.5-, 3.7-, and 4.9-fold for p53 gene and increased by 4.6-, 5.2-, and 8.1-fold for caspase- 3 gene, respectively, compared with control mice (Figs. 2 and 3). Furthermore, the expression levels of p53 and caspase- 3 gene were increased in the groups of mice treated with the active ingredient of DZN pesticide compared with the control group, where the expression levels increased by 3.4-, 2.9-, and 4.6-fold for p53 and increased by 3.2-, 3.7, and 5.4-fold for Caspase-3 gene, respectively (Figs. 2 and 3). Furthermore, the results showed that the expression levels of p53 and caspase- 3 genes were higher in the groups of mice treated with the commercial formulation of DZN pesticide than those treated with an active ingredient of DZN pesticide.

In accordance with these findings, Abdel-Diam et al. (2019) reported that DZN caused the induction of neurohepatic inflammation and caused oxidative damage. This was confirmed by a significant induction of the liver and kidney enzymes such as alanine and aspartate aminotransferases, gamma-glutamyl transferase, alkaline phosphatase, lactate dehydrogenase, tumor necrosis factor- $\alpha$, and also acetylcholinesterase activity inhibition. Besides, Razavi et al. (2013) reported that the commercial formulation form of DZN induced apoptosis through the rise of $\mathrm{Bax} / \mathrm{Bcl} 2$ ratio and caspase- 3 gene (both mRNA and protein levels) in cardiac tissue of rats.

Apoptosis is an energy-dependent process, in which phosphatidylserine is transferred outside the plasma membrane, mitochondrial membrane permeability is changed, caspases activated and then transferred to the nucleus, and finally, DNA fragmentation is occurred (Crompton, 2000). Furthermore, several studies proved that organophosphates affect the expression levels of gene-related apoptosis such as pro-apoptotic Bax and antiapoptotic Bcl-2 (Geng et al., 2015; Yu et al., 2015), and through its activation effect on the internal and external pathways, it stimulates apoptosis (Kaur et al., 2007; Saulsbury et al., 2009).

\section{Effect of DZN pesticide on ROS formation}

The effect of the commercial formulation and the active ingredient of DZN pesticide on intracellular ROS changes is shown in Figure 4. The results found that male mice treated with the low and medium doses of the commercial formulation of DZN pesticide showed a significant increase $(p<0.05)$ in the generation of intracellular ROS in kidney tissues. Furthermore, the treatment of male mice with the high dose of a commercial formulation of DZN pesticide increased the intracellular ROS $(p<0.01)$ much more than the low and medium doses compared with the control group.

However, the treatment of male mice with low and medium doses of the active ingredient of DZN pesticide increased slightly with no significant differences $(p>0.05)$ in the generation of intracellular ROS in the kidney tissues compared with the control mice. Moreover, male mice treated with the high dose of the active ingredient of DZN pesticide showed an increase in the intracellular ROS $(p<0.05)$ compared with that of the control group (Fig. 4). Our findings are in deep agreement with the fact that mutagens and carcinogens such as pesticide exposure induce the free radical formation causing damage of the DNA structure

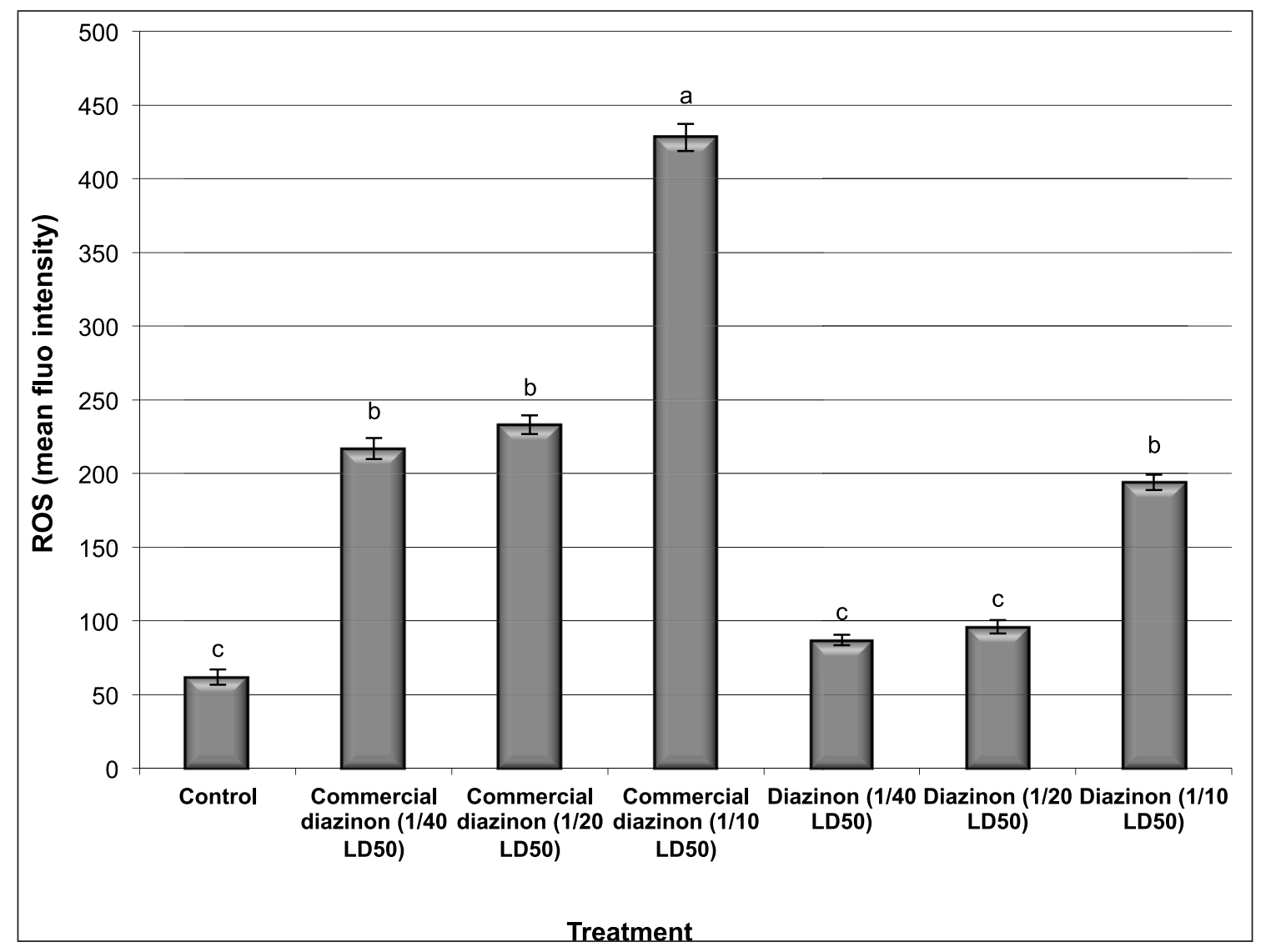

Figure 4. The changes of intracellular ROS levels in kidney tissues of male mice exposed to different concentration of commercial diazinon formulation Basudin $60 \mathrm{EM}^{\circledR}$ and active ingredient of Diazinon. Data are presented as mean $\pm \mathrm{SEM}$. a,b,c Mean values within tissue with unlike superscript letters were significantly different (a: $P<0.01$, b: $P<0.05$ ). 
Table 2. Visual score of DNA damage in liver tissues of male mice exposed to different concentrations of commercial DZN formulation Basudin $60 \mathrm{EM} \Re$ and active ingredient of DZN.

\begin{tabular}{|c|c|c|c|c|c|c|c|c|}
\hline \multirow{2}{*}{ Treatment } & \multirow{2}{*}{ No of samples } & \multicolumn{2}{|c|}{ No. of cells } & \multicolumn{4}{|c|}{ Class $^{* * t}$} & \multirow{2}{*}{ DNA damaged cells $\%($ Mean \pm SEM $)$} \\
\hline & & Analyzed ${ }^{*}$ & Comets & 0 & 1 & 2 & 3 & \\
\hline Control & 5 & 500 & 39 & 461 & 23 & 14 & 2 & $7.81 \pm 0.42^{\mathrm{d}}$ \\
\hline Commercial DZN (1/40 LD50) & 5 & 500 & 86 & 414 & 37 & 23 & 26 & $17.20 \pm 0.65^{\mathrm{b}}$ \\
\hline Commercial DZN (1/20 LD50) & 5 & 500 & 93 & 407 & 28 & 31 & 34 & $18.64 \pm 0.57^{\mathrm{b}}$ \\
\hline Commercial DZN (1/10 LD50) & 5 & 500 & 144 & 356 & 32 & 46 & 66 & $28.83 \pm 0.65^{\mathrm{a}}$ \\
\hline $\mathrm{DZN}_{(1 / 40 \text { LD50) }}$ & 5 & 500 & 71 & 429 & 29 & 24 & 18 & $14.21 \pm 2.48^{c}$ \\
\hline $\mathrm{DZN}_{(1 / 20 \text { LD50) }}$ & 5 & 500 & 79 & 421 & 32 & 22 & 25 & $15.80 \pm 2.63^{\mathrm{bc}}$ \\
\hline $\operatorname{DZN}_{(1 / 10}$ LD50) & 5 & 500 & 92 & 408 & 36 & 27 & 29 & $18.39 \pm 1.35^{b}$ \\
\hline
\end{tabular}

*Number of cells examined per a group, ${ }^{* *}$ Class $0=$ no tail. $1=$ tail length $<$ diameter of nucleus; $2=$ tail length between $1 \mathrm{X}$ and $2 \mathrm{X}$ diameter of nucleus; and $3=$ tail length $>$

$2 \mathrm{X}$ the diameter of nucleus. Commercial DZN formulation Basudin $60 \mathrm{EM} \circledast$; DZN: Active ingredient of DZN. ${ }^{\text {ab,c,d: }}$ Mean values within tissue with unlike superscript letters were significantly different (a: $p<0.01,{ }^{\mathrm{b}} p<0.05$ ).

and thus lead to mutations and/or cell death (Hatjian et al., 2000; Khalil et al., 2011; Scott et al., 1991).

\section{Effect of DZN pesticide on DNA damage}

Table 2 shows the effect of the commercial formulation and the active ingredient of DZN pesticide on the DNA damage in the liver tissues of male mice. The results revealed that the treatment of male mice with the low and medium doses of the commercial formulation of DZN pesticide significantly increased the DNA damage $(p<0.05)$ in liver tissues. Besides, the treatment of male mice with the high dose of a commercial formulation of DZN pesticide increased the DNA damage $(p<0.01)$ much more than the low and medium doses compared with the control group. Furthermore, the treatment of male mice with the low, medium, and high doses of the active ingredient of DZN pesticide increased the DNA damage $(p<0.05)$ compared with the control group. These results indicated that the commercial formulation of DZN pesticide was able to induce DNA damage in liver tissues more than the active ingredient of DZN pesticide.

In agreement with the finding, Yassa et al. (2011) reported that DZN induces chromosomal aberrations such as sister chromatid exchanges. In this study, the assay of DNA damage was evaluated by comet associated with ROS generation assay. Such DZN-induced damage might be attributed to its apoptotic action induced by the intracellular ROS generation increase. As mentioned previously, organophosphate compounds cause different features of cellular damages that mainly affect DNA structure and performance (Maxwell and Dutta, 2005). Piña-Guzmán et al. (2005) proved that organophosphate toxicity is mediated by nuclear protein phosphorylation, and its alkylation characteristics can affect DNA. Hence, organophosphates, including DZN, cause chromatin structure and sperm DNA changes in the liver tissues. Therefore, the ROS generation produced during the DZN metabolism in the liver can induce DNA damage, which was clearly observed in the commercial formulation form of DZN.

The purpose of the emulsifiable formulations was to prevent the breakdown of DZN into its toxic byproducts inducing DNA damage. However, the fact that the formulation used in this study was more toxic, suggesting that the chosen commercial DZN formulation Basudin 60EM ${ }^{\circledR}$ was not effective in preventing the degradation of DZN in the hydrocarbon-based/emulsifiable inducing genotoxic effects. In agreement with the findings, Muranli et al. (2015) reported that commercial DZN formulation Basudin $60 \mathrm{EM}{ }^{\circledR}$ increased micronucleus formation and DNA damage in human lymphocytes compared to control, suggesting that this commercial form could not prevent the breakdown of DZN into its toxic byproducts.

\section{CONCLUSION}

Commercial DZN formulation Basudin 60EM $\AA$ induced a genetic and biochemical modulation much more than the active ingredient form of DZN, and this revealed that not only the organophosphates but also the other byproducts affect cellular responses to cytokine (TNF- $\alpha$ ) and apoptotic elements through changes in the gene expression as a result of rise in a free radical generation. In this study, the increased DNA damage in the liver and kidney cells boosts a major concern regarding the current health risk assessment posed by the form of the used pesticide and the need for a high level of usage caution in agriculture and household.

\section{ACKNOWLEDGMENT}

The authors would like to thank Dr. Maher Abdel Aleem in the Department of Plant Protection of the Faculty of Agriculture, Ain Shams University, for providing us generously with the pesticides needed for this study.

\section{AUTHORS' CONTRIBUTION}

All authors have contributed to the plan of work of the study and carrying out the experimental work as well as analysis of the obtained data. Khalil WKB has finalized and drafted the manuscript.

\section{CONFLICT OF INTEREST}

The authors declared that they do not have any conflicts of interest.

\section{FUNDING}

None.

\section{REFERENCES}

Abdel-Diam MM, Samak DH, El-Sayed YS, Aleya L, Alarifi S, Alkahtani S. Curcumin and quercetin synergistically attenuate subacute 
Diazinon-induced inflammation and oxidative neurohepatic damage, and acetylcholinesterase inhibition in albino rats. Environ Sci Pollut Res, 2019; 26(4):3659-65.

Allison DF, Pamela JL, Angela SH, Bethany LY, Rondell AB, Jett DA. Mechanisms of organophosphate insecticide- Induced airway hyperreactivity. Am J Physiol lung Cell Mol Physiol 2004; 286: 963-969.

Altamirano-Lozano MA, Camacho-Chamomile M. del C, Loyola-Alvarez-Reyes Elia Roldan R. Mutagenic and teratogenic effects of Diazinon. Rev Int Contam Ambie, 1989; 5:49-58.

Bianchi-Santamaria A, Gobbi M, Cembran M, Arnaboldi A. Human lymphocyte micronucleus genotoxicity test with mixtures of phytochemicals in environmental concentrations. Mutat Res, 1997; 388:27-32.

Blasiak J, Arabski M, Krupa R, Wozniak K, Zadrozny M, Kasznikcki J, Zurawska M, Drzewoski J. DNA damage and repair in type 2 diabetes mellitus. Mutat Res, 2004; 554(1-2):297-304.

Cantor KP, Blair A, Everett G, Gibson R, Burmeistep LF, Brown LM, Schuman L, Dick FR. Pesticides and other agricultural risk factors for non-Hodgkin's lymphoma among men in Iowa and Minnesota. Cancer Res, 1992; 52(9):2447-55.

Casas E, Bonilla E, Ducolomb Y, Betancourt M. Differential effects of herbicides atrazine and fenoxaprop-ethyl, and malathion, on viability and maturation of porcine oocytes in vitro. Toxicol In Vitro, 2010; 24(1):224-30.

Chen HH, Hsueh JL, Sirianni SR, Huang CC. Induction of sister-chromatid exchanges and cell cycle delay in cultured mammalian cells treated with eight organophosphorus pesticides. Mutat Res, 1981; 88(3):307-16.

Colovic M, Krstic D, Petrovic S, Leskovac A, Joksic G, Savic J, Franko M, Trebse P, Vasic V. Toxic effects of Diazinon and its photodegradation products. Toxicol Lett, 2010; 193(1):9-18.

Cox C. Diazinon: toxicology. J Pest Reform, 2000; 20(2): $15-21$.

Crompton M. Bax, Bid and the permeabilization of the mitochondrial outer membrane in apoptosis. Curr Opin Cell Biol, 2000; 12(4):414-9.

Ducolomb Y, Casas E, Valdez A, Gonzales G, AltamiranoLozano M, Betancourt M. In vitro effect of malathion and Diazinon on oocyte fertilization and embryo development in porcine. Cell Biol Toxicol, 2009 ; 25(6):623-33.

El-Shenawy NS, Al-Eisa RA, El-Salmy F, Salah O. Prophylactic effect of vitamin E against hepatotoxicity, nephrotoxicity, hematological induces and histopathology induced by Diazinon insecticide in mice. Curr Zool, 2009; 55(3):219-26.

Geng X, Shao H, Zhang Z, Ng JC, Peng C. Malathion-induced testicular toxicity is associated with spermatogenic apoptosis and alterations in testicular enzymes and hormone levels in male Wistar rats. Environ Toxicol Pharmacol, 2015; 39(2):659-67.

Hatjian BA, Mutch E, Williams FM, Blain PG, Edwards JW. Cytogenetic response without changes in peripheral cholinesterase enzymes following exposure to a sheep dip containing Diazinon in vivo and in vitro. Mutat Res, 2000; 472(1-2):85-92.

Kaur P, Radotra B, Minz RW, Gill KD. Impaired mitochondrial energy metabolism and neural apoptotic cell death after chronic dichlirvos (OP) exposure in rat brain. Neurotoxicology, 2007; 28(6): 1208-19.

Khalil WK, Abdu F. Effects of salvia officinalis extract and its nano-encapsulated form on methylmercury induced neurotoxic-stress in male rats. World Appl Sci J, 2013; 24(7):826-37.

Khalil WK, Girgis E, Emam AN, Mohamed MB, Rao KV. Genotoxicity evaluation of nanomaterials: DNA damage, Micronuclei, and 8-Hydroxy-2-deoxyguanosine induced by magnetic doped CdSe quantum dots in male mice. Chem Res Toxicol, 2011; 24(5):640-50.

Khalil WKB, Booles HF, Hafiz NA, El-Bassyouni GE. Ameliorative effects of brachidontes variabilis calcium carbonate against bone loss in ovariectomized rats. Int J Pharmacol, 2018; 14:477-87.
Khan HA, Abdelhalim MA, Alhomida AS, Al Ayed MS. Transient increase in IL- $1 \beta$, IL- 6 and TNF- $\alpha$ gene expression in rat liver exposed to gold nanoparticles. Genet Mol Res, 2013; 12(4):5851-7.

Kuroda K, Yamaguchi Y, Endo G. Mitotic toxicity, sister chromatid exchange, and rec assay of pesticides. Arch Environ Contam Toxicol, 1992; 23(1):13-8.

Lopez D, Aleixandre C, Merchan M, Carrascal E. In vitro induction of alterations in peripheral blood lymphocytes by different doses of Diazinon. Bull Environ Contam Toxicol, 1986; 37(1):517-22.

Maxwell LB, Dutta HM. Diazinon-induced endocrine disruption in bluegill sunfish, Lepomis macrochirus. Ecotox Environ Safe, 2005; 60(1):21-7.

Muranli FDG, Kanev M, Ozdemir K. Genotoxic effects of diazinon on human peripheral blood lymphocytes. Arh Hig Rada Toksikol, 2015; 66(2):153-8

Ogutch A, Uzunhisarcikli M, Kalender S, Durak D, Bayrakdar F, Kalender Y. The effects of organophosphate insecticide Diazinon on malondialdehyde levels and myocardial cells in rat heart tissue and protective role of vitamine E. Pestic Biochem Phys, 2006; 86(2):93-8.

Piña-Guzmán B, Solís-Heredia MJ, Quintanilla-Vega B. Diazinon alters sperm chromatin structure in mice by phosphorylating nuclear protamines. Toxicol Appl Pharmacol, 2005; 202(2):189-98.

Rasmy GE, Khalil WK, Moharib SA, Kawkab AA, Jwanny, EW. Dietary fish oil modulates the effect of dimethylhydrazine-induced colon cancer in rats. Grasas y Aceites, 2011; 62(3):253-67.

Razavi BM, Hosseinzadeh H, Movassaghi AR, Imenshahidi M, Abnous K. Protective effect of crocin on Diazinon induced cardiotoxicity in rats in subchronic exposure. Chem Biol Interact, 2013; 203(3):547-55.

Salem NA, Wahba MA, Eisa WH, El-Shamarka M, Khalil W. Silver oxide nanoparticles alleviate indomethacin-induced gastric injury: a novel antiulcer agent. Inflammopharmacology, 2018; 26:1025-35.

SAS Performance Tuning Strategies and Techniques Institute. SAS User's Guide: statistics. SAS Institute Inc., Cary, NC, 2003.

Satar S, Kayraldiz A, Rencuzogullari E, Karakoc E, Sebe A, Avci A, Yesilagac H, Topaktas M. The genotoxicity and cytotoxicity among patients diagnosed with organophosphate poisoning. Bratisl Lek Listy, 2009; 110(8):476-9.

Saulsbury MD, Heyliger SO, Wang K, Johnson DJ. Chlorpyrifos induces oxidative stress in oligodendrocyte progenitor cells. Toxicology, 2009; 259(1-2):1-9.

Scott D, Galloway SM, Marshall RR, Ishidate M Jr, Brusick $\mathrm{D}$, Ashby J, Myhr BC. International commission for protection against environment mutagens conditions. A report from ICPEMC task group 9. Mutat Res, 1991; 257(2):147-205.

Sobti RC, Krishan A, Pfaffenberger CD. Cytokinetic and cytogenetic effects of some agricultural chemicals on human lymphoid cells in vitro: organophosphates. Mutat Res, 1982; 102(1):89-102.

Vettorazzi G, Vettorazzi PM. Safety evaluation of chemicals in Food: toxicological data profiles for pesticides 1. Carbamate and organophosphorus insecticides used in agriculture and public health. Bull World Health Organ, 1975; 52(Suppl 3):1-61.

Wang P, Li H, Hassan MM, Guo Z, Zhang ZZ, Chen Q. Fabricating an acetylcholinesterase modulated UCNPs-Cu2+ fluorescence biosensor for ultrasensitive detection of organophosphorus pesticidesDiazinon in food. J Agric Food Chem, 2019; 67(14):4071-9.

Yassa VF, Girgis SM, Abumourad IMK. Potential protective effects of vitamin E on Diazinon-induced DNA damage and some hematological and biochemical alterations in rats. J Mediterr Ecol, 2011; 11:31-9.

Yonguc GN, Dodurga Y, Kurtulus A, Boz B, Acar K. Caspase 1, caspase 3, TNF-alpha, p53, and Hif1-alpha gene expression status of the brain tissues and hippocampal neuron loss in short-term dichlorvos exposed rats. Mol Biol Rep, 2012; 39(12):10355-60.

Yu K, Li G, Feng W, Liu L, Zhang J, Wu W, Xu L, Yan Y. Chlorpyrifos is estrogenic and alters embryonic hatching, cell proliferation and apoptosis in zebrafish. Chem Biol Interact, 2015; 239:26-33. 
Zhang H, Qiao J, Li G, Zhang M, Li S, Wang J, Song Y. Construction of coated Z-scheme Pd-BaZrO3@WO3 composite with enhanced sonocatalytic activity for Diazinon degradation in aqueous solution. Sci Total Environ, 2019; 663:97-109.

How to cite this article:

Ali NI, Salem LM, Elateek SY, Khalil WKB. Modulation impact of Diazinon forms on Gene expression profile and DNA damage pathway in male mice. J Appl Pharm Sci, 2020; 10(08):067-074. 